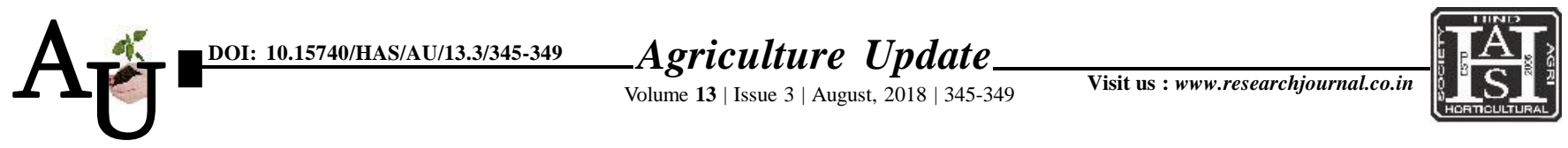

口 ISSN-0976-6847

\title{
Research article: Constraint analysis in use of soil and water conservation practices by the farmers in Amravati district, Maharashtra
}

\section{S.S. Kadam, S.U. Mokhale, S.N. Gawande and N.N. Dhote}

Article Chronicle : Received : 02.05.2018;

Revised : 30.06.2018;

Accepted : 14.07.2018

KEY Words : Constraint, SWCPs, Overall constraint severity index, Knowledge, Adoption, Mean constraint severity score

Author for correspondence :

\section{S.U. Mokhale}

Department of Extension Education, Shri Shivaji Agriculture College, Amravati (M.S.) India

Email : shekharmokhale $17 @$ gmail.com

See end of the article for authors' affiliations
SUMMARY : A survey of 80 proportionately selected sample of farmers from Morshi and Amravati talukas of Amravati district of Vidarbha in Maharashtra revealed that majority of farmers had second category i.e. severe to some extent category of overall constraint severity index of SWCPs. Age, education, occupation, annual income, social participation, knowledge and adoption had no significant relationship with overall constraint severity index and land holding and extension contact had negatively significant with overall constraint severity index.

How to cite this article : Kadam, S.S., Mokhale, S.U., Gawande, S.N. and Dhote, N.N. (2018). Constraint analysis in use of soil and water conservation practices by the farmers in Amravati district, Maharashtra. Agric. Update, 13(3): 345-349; DOI : 10.15740/HAS/AU/13.3/345-349. Copyright@ 2018: Hind Agri-Horticultural Society. 